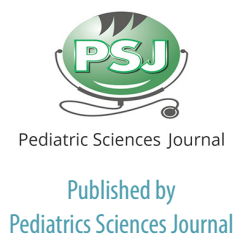

\section{Mechanical ventilation practice of pediatric patients with Covid-19 in Indonesian tertiary hospital}

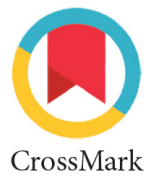

\author{
Kurniawan Taufiq Kadafi*, Erviani Maulidya, William Prayogo Susanto, \\ Saptadi Yuliarto
}

Division of Pediatric Emergency and Intensive Care, Department of Pediatrics, Faculty of Medicine, Universitas Brawijaya, Saiful Anwar General Hospital, Indonesia

\author{
*Corresponding to: \\ Kurniawan Taufiq Kadafi; \\ Division of Pediatric Emergency and \\ Intensive Care, Department of Pediatrics, \\ Faculty of Medicine, Universitas \\ Brawijaya, Saiful Anwar General \\ Hospital, Indonesia \\ kadafi12.fk@ub.ac.id
}

Received: 2021-03-16

Accepted: 2021-05-20

Published: 2021-06-01

\section{ABSTRACT}

Background: Coronavirus Disease-2019 (COVID-19) in children tend to have milder clinical manifestation. However, some develop critical conditions and require mechanical ventilation in the Pediatric Intensive Care Unit (PICU). Various modalities are recommended for mechanical ventilation, such as High Flow Nasal Cannula (HFNC), Continuous Positive Airway Pressure (CPAP), or invasive ventilation with intubation. This study aims to describe the clinical feature, ventilation modalities usage, and the outcome of children with critical COVID-19.

Methods: This is a retrospective study in COVID-19 children with respiratory distress who were treated in the COVID-19 isolation PICU room of Saiful Anwar General Hospital for one year. The data was gained from the medical record and analyzed descriptively. Data were analyzed using Ms. Excel for Windows.

Results: A total of 51 children with COVID-19 were admitted to Saiful Anwar general Hospital in one year period, with 12 of them in critical condition and 6 children require mechanical ventilation. The main signs developed were fever and dyspnea. Invasive mechanical ventilation applicated in 5 patients, and only 1 patient received Non-Invasive Ventilation (NIV). The mean of PEEP used in invasive ventilation is 7-9 $\mathrm{cmH}_{2} 0$, lower than ESPNIC's recommendation of 8-10 $\mathrm{cmH}_{2} 0$. Length of ventilator usage is $2-21$ days, with 2 patients passed away, both with a comorbid and organ system injury.

Conclusion: The mechanical ventilation setting must be determined individually based on the patients' condition, despite several guidelines providing the recommendation.

Keywords: Mechanical Ventilation Practice, Pediatric, Covid-19.

Cite This Article: Kadafi, K.T., Maulidya, E.M., Susanto, W.P., Yuliarto, S. 2021. Mechanical ventilation practice of pediatric patients with Covid-19 in Indonesian tertiary hospital. Pediatrics Sciences Journal 2(1): 15-19.

\section{INTRODUCTION}

Severe Acute Respiratory Syndrome Coronavirus-2 (SARS-CoV-2) is the agent causing Coronavirus disease 19 (COVID-19). ${ }^{1}$ SARS-CoV-2 has the ability to pathogenically and quickly spreading, causing a pandemic and broad multidisciplinary effect. ${ }^{2}$ COVID-19 can occur in all-age children, with $<5 \%$ prevalence worldwide. The fatality of COVID-19 in children $<0.1 \%$ from the total, which is much lower than fatality in the adults and elderly, around 5-15\%., ${ }^{1,3,4}$ In Indonesia, the prevalence of pediatric COVID-19 is $12.5 \%$ from total cases with $1.2 \%$ fatality, which is higher than worldwide. ${ }^{5}$

COVID-19 in children reported in several studies to have a milder clinical manifestation. However, 2\% of pediatric COVID-19 showed severe clinical manifestation and some of them have a critical condition. ${ }^{6}$ In pediatric COVID-19, desaturation $\left(\mathrm{SpO}_{2}<92 \%\right)$ occurred in $1-2.3 \%$, with $8 \%$ requires PICU and $4 \%$ requires mechanical ventilation. ${ }^{7-9}$ Several countries already recommend mechanical ventilation application in children with COVID-19. The Paediatric Mechanical Ventilation Consensus Conference (PEMVECC) and the section on respiratory failure from the European Society for Paediatric and Neonatal Intensive Care (ESPNIC) recommend the application of Continuous Positive Airway Pressure (CPAP) or Bi-Level NonInvasive Ventilation (NIV) as a first oxygen therapy choice in pediatric COVID-19 with ARDS in $\mathrm{SpO}_{2} / \mathrm{FiO}_{2}$ between 221 and $264 .{ }^{10} \mathrm{CPAP}$ or Bi-Level NIV is more recommended than High Flow nasal Cannula (HFNC). HFNC is considered if there is no CPAP/Bi-level NIV and the patient still has $\mathrm{SpO}_{2} / \mathrm{FiO}_{2}>264\left(\mathrm{FiO}_{2}\right.$ $<0.35-0.4)$. Intubation is mandatory if $\mathrm{SpO}_{2} / \mathrm{FiO}_{2}$ is less than 221 and inpatient with refractory respiratory distress (no improvement after oxygen therapy with CPAP/NIV with $\mathrm{SpO}_{2}$ target of $92-97 \%$ and $\mathrm{FiO}_{2}<0.6$ for $60-90$ minutes). ${ }^{10}$ If the patient uses HFNC, intubation indicated no improvement after oxygen therapy with a $\mathrm{SpO}_{2}$ target of $92-97 \%$ and $\mathrm{FiO}_{2}<$ 0.4 for 30-60 minutes. Invasively ventilated patients are recommended to have a lungprotective ventilation therapy approach with Vte 5-7 mL/kgBW, Pplat <28-32 $\mathrm{cmH}_{2} \mathrm{O}$, driving pressure $\leq 15 \mathrm{cmH}_{2} \mathrm{O}$. The low tidal volume is needed in poor compliance lung. Positive End Expiratory 
Pressure (PEEP) starts from $10 \mathrm{cmH}_{2} \mathrm{O}$ and might be increased gradually. ${ }^{10}$ This recommendation was also adopted in COVID-19 Management Guideline in Indonesia. ${ }^{11}$

Several literatures recommend oxygen therapy in a critical patient based on the type of lung injury, H-type (high elastance, low compliance), and L-type (low elastance, high compliance). NIV respiratory support is recommended in children with moderate Acute Respiratory Distress Syndrome (ARDS), and High Flow Nasal Oxygen (HFNO) therapy is recommended in children with mild ARDS. Invasive ventilation in pediatric COVID-19 with H-type lung injury is recommended to use PEEP 10-12 $\mathrm{cmH}_{2} \mathrm{O}$, tidal volume 4-6 mL/KgBW, $\Delta \mathrm{P}<15$ $\mathrm{cmH}_{2} \mathrm{O}$, Pplat $<30 \mathrm{cmH}_{2} \mathrm{O}$, and $\mathrm{FiO} 2<0.6$. Meanwhile, in the L-type lung injury, it is recommended to use invasive ventilation with PEEP 8-10 $\mathrm{cmH}_{2} \mathrm{O}$, tidal volume 6-8 $\mathrm{mL} / \mathrm{KgBW}, \Delta \mathrm{P}<15 \mathrm{cmH}_{2} \mathrm{O}$, and $\mathrm{FiO} 2$ $<0.6 .^{12,13}$ Other recommendations suggest HFNC application in pediatric COVID-19 with critical symptoms after failed Low Flow Nasal Cannula (LFNC) therapy. Work of breathing and hypoxemia increase are the indication of therapy escalation into NIPPV or BiPAP. ${ }^{14}$

Recently, mechanical ventilation in children with Covid-19 is still not much reported. This study aims to describe the clinical feature of children with severe and critical COVID-19, ventilator setting used, length of ventilator application, and the outcome of pediatric COVID-19 with mechanical ventilation.

\section{METHODS}

We performed a retrospective review study in children with respiratory distress and respiratory failure, whom COVID-19 confirmed from medical records. The data recorded including age, gender, body weight, organ system involvement, any comorbid, clinical feature on hospital admission, type and length of mechanical ventilation used, maximum $\Delta \mathrm{P}$ and PEEP, and the patient's outcome. This study was performed in the COVID-19 isolation PICU room of Saiful Anwar General Hospital from April 2020 to April 2021. The inclusion criteria were children aged 0-18 years and confirmed COVID-19 with RT-PCR test results. The

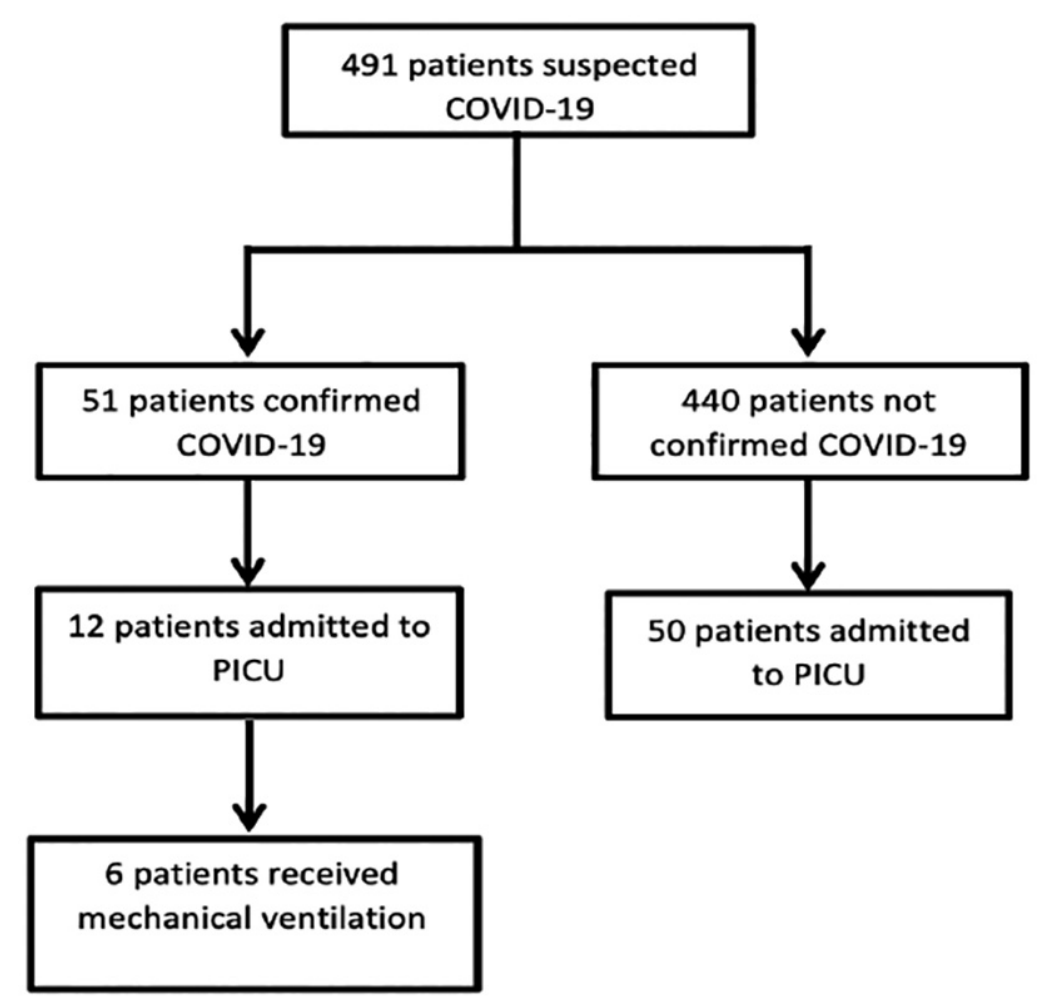

Figure 1. Research flowchart enrolled in this study

exclusion criteria were the mechanical ventilation used for other causes or incomplete patients' data-consecutive sampling was used in this study. Results are descriptive and presented as absolute numbers and percentages, analyzed by Ms. Excel software. A research flowchart is mentioned in Figure 1.

\section{RESULTS}

Over 1 year period, 491 children with suspect COVID-19 and 51 children of them were positively COVID-19 confirmed. There were 62 patients treated in the COVID-19 isolation PICU room, with 12 of them positively COVID-19 confirmed. Of the suspect patients, 40 were male, and 25 used mechanical ventilation, as seen in Table 1. Dominant symptoms of suspect COVID-19 patients on hospital admission were dyspnea (40 patients), fever (36 patients), and dry cough (23 patients), as seen in Figure 2. From the COVID-19confirmed patients only, 6 patients used mechanical ventilation, as seen in Table 2. Dominant symptoms of COVID-19 confirmed on hospital admission were dyspnea and fever, as seen in Figure 3.

All of the COVID-19 confirmed patients who received mechanical ventilation had a problem in the respiratory system and were comorbid, as seen in Table 3. About 5 patients received invasive mechanical ventilation and 1 patient received NIV. The maximum PEEP used was 7-9 $\mathrm{cmH} 2 \mathrm{O}$ with a length of mechanical ventilation between 2-21 days, as seen in Table 3.

\section{DISCUSSION}

COVID-19 number gradually increases, as WHO recorded 175,987,176 COVID-19 cases and 3,811,561 fatal cases on June $15^{\text {th }} \cdot{ }^{15}$ In Indonesia, 1,531,005 COVID-19 patients with 42.666 fatal cases on June $17^{\text {th }}$. COVID-19 in children occurred in $12.5 \%$ of total COVID-19 prevalence with $1.2 \%$ fatal cases. $^{16}$ Pediatric COVID-19 patients in Indonesia are relatively high compared to global prevalence. There are $3 \%$ pediatric COVID-19 prevalence worldwide with various mortality rates. ${ }^{17}$ Mortality rates of pediatric COVID-19 are $1.6 \%$ in the USA, $2.14 \%$ in England, $1.81 \%$ in Italy, $0.64 \%$ in Germany, 3.97\% 
Table 1. Basic Characteristics of Children with COVID-19 Admitted to PICU

\begin{tabular}{lcc}
\hline \multicolumn{1}{c}{ Characteristics } & All Suspected Cases $(\mathbf{n = 6 2 )}$ & Confirmed Cases $(\mathbf{n}=\mathbf{1 2})$ \\
\hline Male gender, n (\%) & $40(65.0)$ & $8(67.0)$ \\
Mechanical ventilation, n (\%) & $25(40.0)$ & $6(50.0)$ \\
- Invasive $\quad 10(40.0)$ & $4(67.0)$ \\
- Non-Invasive $\quad 15(60.0)$ & $2(33.0)$ \\
ECMO, n (\%) & $0(0.0)$ & $0(0.0)$ \\
Survivor, n (\%) & $51(82.0)$ & $10(83.0)$ \\
\hline
\end{tabular}

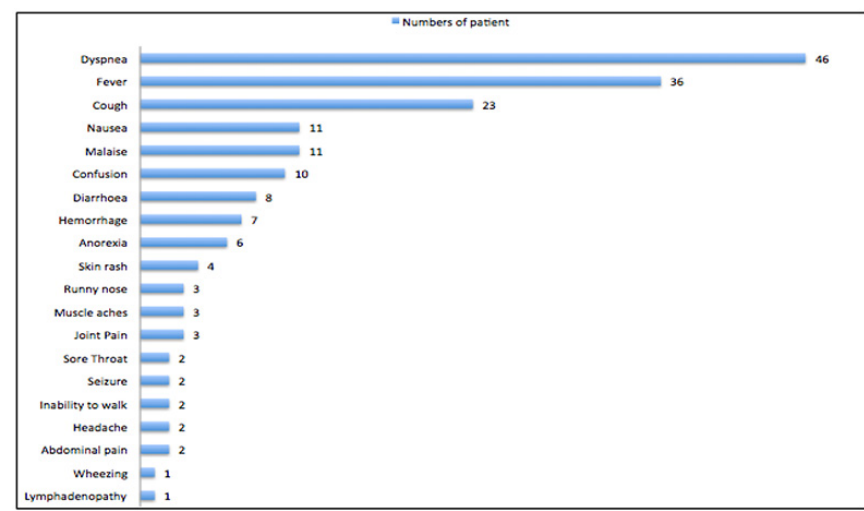

Figure 2. Main Signs \& Symptoms of Suspect COVID-19 Children Admitted to PICU

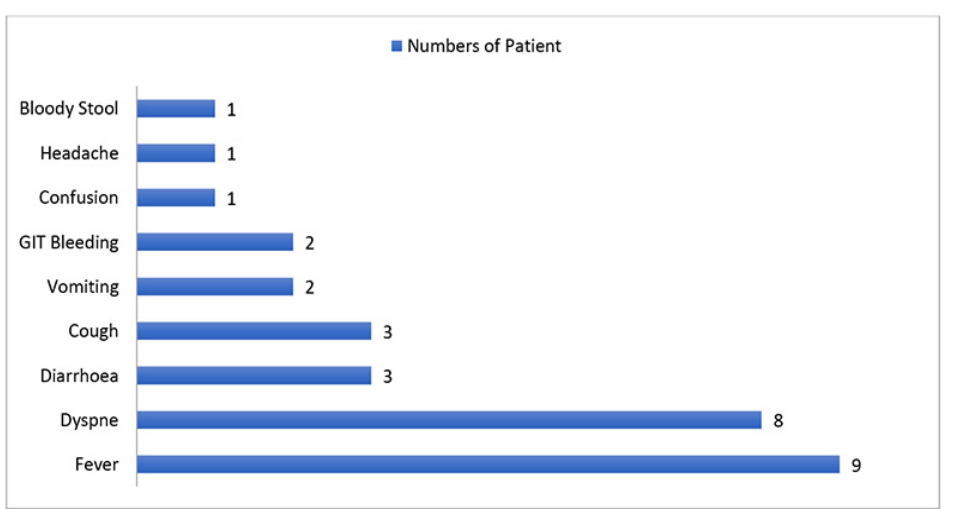

Figure 3. Main Signs and Symptoms of Confirmed COVID-19 Children Admitted to PICU

Table 2. Demographic Characteristics, Organ System Involvement, and Comorbidity from Children with COVID-19 who Receive Mechanical Ventilation on Isolation PICU

\begin{tabular}{|c|c|c|c|c|c|c|c|c|c|}
\hline \multicolumn{4}{|c|}{ Demographic Characteristics } & \multicolumn{4}{|c|}{ Organ System Involvement } & \multicolumn{2}{|c|}{ Comorbid } \\
\hline Case & Age & Gender & $\begin{array}{l}\text { Body Weight } \\
\text { (Kg) }\end{array}$ & GIT & Cardiovascular & Respiratory & Hematologic & Yes & No \\
\hline Case 1 & 43 days & Male & 3,5 & & & & 0 & & \\
\hline Case 2 & 13 months & Female & 5,5 & & & & & & \\
\hline Case 3 & 16 years & Male & 71 & & & & & & \\
\hline Case 4 & 9 years & Male & 18 & & & & & & \\
\hline Case 5 & 41 days & Male & 4,1 & & & & & & \\
\hline Case 6 & 13 years & Female & 29 & & & & & & \\
\hline
\end{tabular}

Table 3. Mechanical Ventilation Characteristics of the Children with COVID-19 who Receive Mechanical Ventilation on Isolation PICU

\begin{tabular}{|c|c|c|c|c|c|c|c|c|}
\hline \multicolumn{4}{|c|}{ Demographics Characteristics } & \multirow{2}{*}{$\begin{array}{c}\text { Type of Mechanical } \\
\text { Ventilation }\end{array}$} & \multirow{2}{*}{$\begin{array}{l}\text { Length of } \\
\text { Ventilation }\end{array}$} & \multirow{2}{*}{$\begin{array}{l}\text { Delta } \\
\text { P max }\end{array}$} & \multirow{2}{*}{$\begin{array}{l}\text { PEEP } \\
\max \end{array}$} & \multirow{2}{*}{ Outcome } \\
\hline Case & Age & Gender & Body Weight (Kg) & & & & & \\
\hline 1 & 43 days & Male & 3.5 & Invasive & 7 days & 14 & 9 & Not survive \\
\hline 2 & 13 months & Female & 5.5 & Invasive & 21 days & 12 & 9 & Survive \\
\hline 3 & 16 years & Male & 71.0 & Invasive & 2 days & 12 & 7 & Not survive \\
\hline 5 & 41 days & Male & 4.1 & Invasive & 6 days & 11 & 7 & Survive \\
\hline 6 & 13 years & Female & 29.0 & Non- Invasive & 15 days & 12 & 7 & Survive \\
\hline
\end{tabular}


in Spain, and $0.62 \%$ in France. ${ }^{18}$ The problem of determining the diagnosis still frequently occurs, as the clinical manifestation and laboratory examination are not specific and their parents don't have a good initiative to check the COVID-19 in symptomatic children, causing COVID-19 number in children not well-described. ${ }^{19}$

Most children with COVID-19 develop mild to moderate symptoms, and fever is the most frequently found (56\%). Other symptoms which often occur are dry cough (54\%) and dyspnea (33\%). Joint pain (23\%) and headache $(28 \%)$ are less frequent but sometimes also developed. In neonates or infants with COVID-19, frequent symptoms are fever and lethargy. ${ }^{20}$ These characteristics are similar to our study, with the most frequent symptom on hospital admission is fever. However, we found more dyspnea symptoms than a cough, different from the previous study. The respiratory problem of many children with COVID-19 we treated might describe the relatively higher amount of dyspnea symptoms. About 50\% (6 from 12) of children with COVID-19 treated in PICU have a respiratory problem and use the ventilator.

Compared to adults, COVID-19 in children less frequently causing severe clinical manifestation and critical conditions. SARS-CoV-2 enters the host cell by attaching viral spike (S) protein with angiotensin-converting enzyme 2 (ACE2) receptor and the priming of $S$ protein by a host protease, such as TMPRSS2. ${ }^{20,21}$ This attachment inhibits the enzyme physiologic activity, internalization, and disrupts the angiotensin balance, reducing the protection of the ACE2expressing organ, such as the lungs. Accor coding from lungs snRNA-seq data of all age groups, there is an increase of ACE2 and TMPRS2-expressing alveoli epithelial proportion in adults than in children. This description suggests less infection and replication of SARS-CoV-2 in pediatric lungs. Another hypothesis of COVID-19 milder symptoms in children is that microbiologically, the SARS-CoV-2 infection occurred simultaneously with other virus infections. Inhibition of virus replication happens by a competitive mechanism. Normal flora on the airway tract is also suspected to reduce the colonization and replication of SARSCoV-2. Less mobility of the children with school closure also reduces the exposure to the children..$^{20,21}$

Although most clinical symptoms in pediatric COVID-19 are mild to moderate, $2 \%$ of them experienced severe clinical manifestations requiring critical care. Previous studies reported $8 \%$ of children with COVID-19 were treated in PICU and $4 \%$ requires mechanical ventilation..$^{7-9}$ In our study, the proportion is even higher, with 12 from 51 children with COVID-19 treated in PICU (23.5\%) and 6 children (11.76\%) requires mechanical ventilation. A previous study from Dewi $\mathrm{R}$ et al., showed a similar result, with 7 from 50 children (14\%) with COVID-19 was in critical condition and treated in PICU..$^{22} \mathrm{~A}$ better proportion reported by Katayama et al. with only 1 from 150 patients (0.7\%) requires mechanical ventilation. ${ }^{23}$ These differences might be explained by the different health statuses of the children before the pandemic starts.

PEMVECC and ESPNIC recommend using CPAP or Bi-level NIV as a first oxygen therapy choice in COVID-19 children with ARDS and $\mathrm{SpO}_{2} / \mathrm{FiO}_{2}$ between 221 and 264. CPAP and Bi-level NIV are more recommended than HFNC, but HFNC can be considered where the CPAP/NIV is unavailable and $\mathrm{SpO}_{2} / \mathrm{FiO}_{2}$ is above 264 . Invasive mechanical ventilation guided by lung-protective ventilation approach with PEEP starts from $10 \mathrm{cmH} 2 \mathrm{O}$ and can be increased gradually if needed..$^{10}$ The recent recommendation in 2021 from ESPNIC mentions the new PEEP recommendation is on $8-10 \mathrm{cmH} 2 \mathrm{O}$ and might be increased based on $\mathrm{PEEP} / \mathrm{FiO}_{2} \cdot{ }^{24}$ In our study, 5 children using invasive mechanical ventilation, and 1 child using non-invasive one. We set the PEEP on 7-9 $\mathrm{cmH}_{2} \mathrm{O}$ for all of the invasive mechanical ventilation according to the recent guideline.

Carvalho WB et al. suggested the PEEP setting is determined by lung elastance and compliance. ${ }^{13}$ Lower PEEP applicated for low lung elastance and high lung compliance patients. ${ }^{13}$ Other studies from Prata-Barbosa A et al. showed a median of maximum PEEP in children with COVID-19 is $9 \mathrm{cmH}_{2} \mathrm{O}$ in non-MISC patients and $12 \mathrm{cmH}_{2} \mathrm{O}^{2}$ in
MISC patients. ${ }^{25}$ These two studied were well-correlated since lower lung elastance and higher lung compliance founded in non-MISC patients, and the PEEP setting was determined similarly. Fisler $\mathrm{G}$ et al., also reported the highest PEEP setting of $12 \mathrm{cmH}_{2} \mathrm{O}$ in children with COVID-19. ${ }^{26}$ Another study in Argentina also recommends the PEEP setting based on lung injury type. High phenotype and low compliance patients received PEEP of $10-14 \mathrm{cmH}_{2} \mathrm{O}$ with tidal volume $<6$ $\mathrm{mL} / \mathrm{KgBW}$, while low phenotype and high compliance patients received PEEP 8-10 $\mathrm{CmH}_{2} \mathrm{O}$ with tidal volume $6-9 \mathrm{~mL} /$ $\mathrm{KgBW} \cdot{ }^{27} \mathrm{In}$ the USA, the recommendation of oxygen therapy using step-up therapy, with HFNC usage if LFNC failed, followed by NIPPV or BiPAP and intubation with invasive mechanical ventilation if needed. ${ }^{14}$ In this study, only 1 patient with COVID-19 received NIV.

Our study's ventilator usage length is 2-21 days and 2 children with COVID-19 who received ventilators passed away. The previous study reported length of ventilator use in children with critical COVID-19 was 8 days in non-MISC patients and 5 days in MISC patients. Mortality rates of pediatric COVID-19 who receive mechanical ventilation are $3 \%$ in non-MISC patients and $0 \%$ in MISC patients. ${ }^{25}$ In our study, all ventilatorreceiving patients had comorbidity and several organ system injuries, worsening the outcome.

This study has a limitation, considering the relatively low number of pediatric COVID-19 with mechanical ventilation cases and the study only done in a single hospital. However, we believe this study contributes to understanding COVID-19 in children with critical conditions, especially with mechanical ventilation application. We conclude despite several centers already recommend respiratory support strategies in children with COVID-19, the mechanical ventilation setting must be determined individually based on each patient's condition.

\section{CONFLICT OF INTEREST}

None of the authors have a conflict of interest to declare 


\section{ETHICS CONSIDERATION}

Ethics approval has been obtained from the Health Research Ethics Commission, Dr. Saiful Anwar Hospital, Malang, Indonesia, with number 400/123/K.3/302/2021 before the study was conducted.

\section{FUNDING}

This study received no funding grant.

\section{AUTHOR CONTRIBUTION}

All authors equally contribute to the study from the conceptual framework, data acquisition, data analysis until interpreting the study results through publication.

\section{REFERENCES}

1. Jurado Hernández JL, Álvarez Orozco IF. COVID-19 in Children: Respiratory Involvement and Some Differences With the Adults. Front Pediatr. 2021;9:622240.

2. Hu B, Guo H, Zhou P, Shi ZL. Characteristics of SARS-CoV-2 and COVID-19. Nat Rev Microbiol. 2021;19(3):141-154.

3. Ali AS, Al-Hakami AM, Shati AA, Asseri AA, Al-Qahatani SM. Salient Conclusive Remarks on Epidemiology and Clinical Manifestations of Pediatric COVID-19: Narrative Review. Front Pediatr. 2020;8:584694

4. Meena J, Yadav J, Saini L, Yadav A, Kumar J. Clinical Features and Outcome of SARS-CoV-2 Infection in Children: A Systematic Review and Meta-analysis. Indian Pediatr. 2020;57(9):820826.

5. Hikmawati I, Setiyabudi R. Epidemiology of COVID-19 in Indonesia: common source and propagated source as a cause for outbreaks. J Infect Dev Ctries. 2021;15(5):646-652.

6. Parisi GF, Indolfi C, Decimo F, Leonardi S, Miraglia Del Giudice M. COVID-19 Pneumonia in Children: From Etiology to Management. Front Pediatr. 2020;8:616622.

7. de Souza TH, Nadal JA, Nogueira RJN, Pereira RM, Brandão MB. Clinical manifestations of children with COVID-19: A systematic review. Pediatr Pulmonol. 2020;55(8):18921899.
8. Lu X, Zhang L, Du H, Zhang J, Li YY, Qu J, et al. SARS-CoV-2 Infection in Children. N Engl J Med. 2020;382(17):1663-1665.

9. Götzinger F, Santiago-García B, NogueraJulián A, Lanaspa M, Lancella L, Calò Carducci FI, et al. COVID-19 in children and adolescents in Europe: a multinational, multicentre cohort study. Lancet Child Adolesc Health. 2020;4(9):653-661.

10. Kneyber MCJ, Medina A, Alapont VMI, Blokpoel R, Brierley J, Chidini G, et al., Practice recommendations for the management of children with suspected or proven COVID-19 infections from the Paediatric Mechanical Ventilation Consensus Conference (PEMVECC) and the section Respiratory Failure from the European Society for Paediatric and Neonatal Intensive Care (ESPNIC); A consensus statement. Paediatric Mechanical Ventilation Consensus Conference: European Society for Paediatric and Neonatal Intensive Care. 2020:1-7.

11. Wati DK, Manggala AK. Overview of management of children with COVID-19. Clin Exp Pediatr. 2020;63(9):345-354.

12. Carlotti APCP, de Carvalho WB, Johnston C, Gilio AE, de Sousa Marques HH, Ferranti JF, et al. Update on the diagnosis and management of COVID-19 in pediatric patients. Clinics (Sao Paulo). 2020;75:e2353.

13. Carvalho WB, Rodriguez IS, Motta EHGD, Delgado AF. Ventilatory support recommendations in children with SarsCoV-2. Rev Assoc Med Bras (1992). 2020;66(4):528-533.

14. Blumenthal JA, Duvall MG. Invasive and noninvasive ventilation strategies for acute respiratory failure in children with coronavirus disease 2019. Curr Opin Pediatr. 2021;33(3):311-318.

15. World Health Organization. WHO Coronavirus (COVID-19) Dashboard. 2021. [Available from: https://covid19.who.int].

16. Satuan Tugas Penanganan COVID-19. Peta Sebaran Covid-19. 2021 [Available from: https://covid19.go.id/peta-sebaran-covid19].

17. Graff K, Smith C, Silveira L, Jung S, CurranHays S, Jarjour J, Carpenter L, Pickard K, Mattiucci M, Fresia J, McFarland EJ, Dominguez SR, Abuogi L. Risk Factors for Severe COVID-19 in Children. Pediatr Infect Dis J. 2021;40(4):e137-e145.
18. Bhopal SS, Bagaria J, Olabi B, Bhopal R. Children and young people remain at low risk of COVID-19 mortality. Lancet Child Adolesc Health. 2021;5(5):e12-e13.

19. Kadafi KT. The difficulty of establishing the diagnosis of pediatric COVID-19 in Indonesia. Ped Sci J. 2020;1(1):39-41.

20. Lingappan K, Karmouty-Quintana H, Davies J, Akkanti B, Harting MT. Understanding the age divide in COVID-19: why are children overwhelmingly spared?. Am J Physiol Lung Cell Mol Physiol. 2020;319(1):L39-L44.

21. Jurado Hernández JL, Álvarez Orozco IF. COVID-19 in Children: Respiratory Involvement and Some Differences With the Adults. Front Pediatr. 2021;9:622240.

22. Dewi R, Kaswandani N, Karyanti MR, Setyanto DB, Pudjiadi AH, Hendarto A, et al. Mortality in children with positive SARS-CoV-2 polymerase chain reaction test: Lessons learned from a tertiary referral hospital in Indonesia. Int J Infect Dis. 2021;107:78-85.

23. Katayama Y, Zha L, Kitamura T, Hirayama A, Takeuchi T, Tanaka K, et al. Characteristics and Outcomes of Pediatric COVID-19 Patients in Osaka, Japan. Int J Environ Res Public Health. 2021;18(11):5911.

24. Rimensberger PC, Kneyber MCJ, Deep A, Bansal M, Hoskote A, Javouhey E, et al. Caring for Critically Ill Children With Suspected or Proven Coronavirus Disease 2019 Infection: Recommendations by the Scientific Sections' Collaborative of the European Society of Pediatric and Neonatal Intensive Care. Pediatr Crit Care Med. 2021;22(1):56-67.

25. Prata-Barbosa A, Lima-Setta F, Santos GRD, Lanziotti VS, de Castro REV, de Souza DC, et al. Pediatric patients with COVID-19 admitted to intensive care units in Brazil: a prospective multicenter study. J Pediatr (Rio J). 2020;96(5):582-592.

26. Fisler G, Izard SM, Shah S, Lewis D, Kainth MK, Hagmann SHF, et al. Characteristics and risk factors associated with critical illness in pediatric COVID-19. Ann Intensive Care. 2020;10(1):171.

27. Taffarel P, Jorro Barón F. Critically-ill pediatric patients with COVID-19. Arch Argent Pediatr. 2020;118(5):e454-e462.

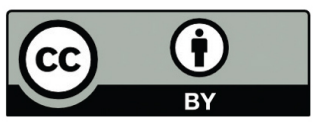

This work is licensed under a Creative Commons Attribution 